\title{
THE REGULATION OF RENAL BICARBONATE REABSORPTION BY PLASMA CARBON DIOXIDE TENSION ${ }^{1}$
}

\author{
By ARNOLD S. RELMAN, BENJAMIN ETSTEN, AND WILLIAM B. SCHWARTZ \\ (From the Evans Memorial, Massachusetts Memorial Hospitals and the New England Center \\ Hospital, and from the Department of Medicine, Boston University School of Medicine \\ and the Departments of Anesthesiology (Surgery) and Medicine, Tufts College \\ Medical School, Boston, Mass.)
}

(Submitted for publication April 29, 1953; accepted June 3, 1953)

\section{INTRODUCTION}

Pitts, Lotspeich, Ayer, and Schiess $(1,2)$ have shown that in acute metabolic acidosis or alkalosis the normal kidney handles bicarbonate as if there were a maximal rate of tubular reabsorption which is a direct linear function of the glomerular filtration rate (approximately 2.5 to $2.8 \mathrm{mEq} . \mathrm{HCO}_{3}$ per 100 cc. GFR, in dog and man). At plasma bicarbonate concentrations significantly below 25 $\mathrm{mEq}$. per L., bicarbonate is completely reabsorbed and the urine is acid. When plasma bicarbonate concentration is elevated above this threshold value all the filtered bicarbonate in excess of the limiting rate is excreted in the urine.

In respiratory disturbances of acid-base balance, however, the bicarbonate threshold must be changed considerably, because in respiratory alkalosis the urine is alkaline despite low plasma bicarbonate concentrations (3-5) and in respiratory acidosis it is acid when plasma bicarbonate is high (6). The mechanisms initiating these changes in bicarbonate transport have not yet been elucidated, although from a priori considerations one would suspect that they must operate through a change in either carbon dioxide tension or extracellular fluid $\mathrm{pH}$. The purpose of this report is to present observations demonstrating that respiratory regulation of bicarbonate reabsorption is effected through changes in carbon dioxide tension and is independent of extracellular fluid $\mathrm{pH}$.

\section{METHODS AND MATERIALS}

Eleven experiments were performed on ten female mongrel dogs weighing 14 to $21 \mathrm{Kg}$. Light general anesthesia was maintained by the intravenous administration of sodium pentobarbital $(12.5 \mathrm{mg}$. per $\mathrm{Kg}$. as a

\footnotetext{
1 Supported in part by grants from the Medical Research and Development Board, Department of the Army, and from the National Heart Institute of the National Institutes of Health, U. S. Public Health Service.
}

2.5 per cent solution). A Magill endotracheal tube fitted with an inflatable balloon was introduced into the trachea and connected in series with a Mine Safety "Pneophore." Respiratory movements were inhibited by the administration of d-tubocurarine chloride $(0.7 \mathrm{mg}$. per $\mathrm{Kg}$.) so that respiratory exchange could be controlled by the intermittent positive pressure device.

In order to assure complete oxygen saturation of arterial blood at all times the animals breathed 95 per cent or 100 per cent oxygen mixtures throughout each experiment. On each of the several occasions when it was checked, saturation of arterial hemoglobin with oxygen was complete despite the wide variations in $\mathrm{pCO}_{2}$. The desired plasma bicarbonate concentrations were achieved by rapid intravenous injection of sodium bicarbonate and maintained by continuous infusion of an approximately isotonic solution of an appropriate mixture of sodium bicarbonate and sodium chloride given at a steady rate of $9.5 \mathrm{cc}$. per min. through a Bowman infusion pump. Glomerular filtration rate was measured by the inulin clearance technique. Frequent blood samples were withdrawn anaerobically into heparinized syringes through a plastic arterial cannula. Urine was collected under neutral mineral oil through an inlying bladder catheter and the bladder was emptied by manual compression at the end of each period. Urine collection periods were usually 10 to 12 minutes long. They were always begun at least 40 minutes after any change in plasma $\mathrm{pH}$ or bicarbonate had been initiated, and at least 20 minutes after plasma $\mathrm{pH}$ and bicarbonate had become essentially constant.

Urine and plasma were analyzed for inulin (7) and for total $\mathrm{CO}_{2}$ content (8). Blood and urine $\mathrm{pH}$ were determined anaerobically at room temperature in a syringetype Cambridge $\mathrm{pH}$ meter and corrected to $37^{\circ} \mathrm{C}$., using an adjustment of $.01 \mathrm{pH}$ unit per degree. Carbon dioxide tension in blood and urine was calculated from the Henderson-Hasselbalch equation, using a value of 6.1 for the $\mathrm{pK}$ in both instances and a value for $\alpha$ in blood of .0301 and in urine of .0309 . Bicarbonate concentrations in plasma and urine were calculated as the difference between the total $\mathrm{CO}_{2}$ content and the dissolved carbonic acid. Filtered bicarbonate was taken as the product of the filtration rate and the plasma bicarbonate concentration.

Three types of experiments were carried out. In the first type, while the animals breathed pure oxygen, carbon dioxide tension was varied by changing pulmonary ventilation. This produced large changes in $\mathrm{pH}$, but the infu- 
sion of sodium bicarbonate assured plasma bicarbonate concentrations high enough to maintain an alkaline reaction (i.e., plasma $\mathrm{pH}$ always greater than 7.45). To control the possible role of neural or humoral influences arising from changes in respiratory mechanics, similar variations in $\mathrm{pCO}_{2}$ were produced with no change in ventilation by the substitution of a 5 per cent carbon dioxide, 95 per cent oxygen mixture for the pure oxygen. In a third group of experiments, $\mathrm{pCO}_{2}$ and plasma bicarbonate were changed simultaneously so that a constant, alkaline plasma $\mathrm{pH}$ was maintained during all the observation periods. This eliminated the possible influence on renal bicarbonate transport of a change in extracellular pH. Urine bicarbonate excretion in every experiment was always sufficiently high to indicate that tubular reabsorptive capacity had been exceeded.

\section{RESULTS}

In all experiments an increase in plasma $\mathrm{pCO}_{2}$, with or without change in extracellular $\mathrm{pH}$, and with or without a change in ventilation, significantly increased the rate of bicarbonate reabsorption, and a decrease in plasma $\mathrm{pCO}_{2}$ decreased bicarbonate reabsorption. The changes in $\mathrm{pCO}_{2}$ produced no consistent or significant alterations in glomerular filtration rate, although in a few experiments the filtration rate tended to decline slightly as the experiment proceeded.

Table I gives the protocol of an experiment typical of seven, in which $\mathrm{pCO}_{2}$ was varied by changing ventilation. The data are illustrated in Figure 1. It is seen that with each change in $\mathrm{pCO}_{2}$ there was an associated change in bicarbonate reabsorption, expressed either in absolute terms (Table I) or corrected to $100 \mathrm{cc}$. GFR. The bicarbonate concentration in the reabsorbate varied with the $\mathrm{pCO}_{2}$ in a similar fashion (Table $I$ and Figure 1). It should be noted that during the last three urine periods the GFR was slightly reduced, but the acute changes in reabsorbate concentration were independent of this phenomenon. The plasma $\mathrm{pH}$ never was lower than 7.46. The changes in plasma bicarbonate level apparently occurred as a result of the renal response to the altered $\mathrm{pCO}_{2}$. In this experiment, as in all others in which the sustaining infusion was not changed, there were no consistent changes in urine flow.

In two experiments in which plasma $\mathrm{pCO}_{2}$ was varied, without changing ventilation, by switching to a 5 per cent $\mathrm{CO}_{2}$ and 95 per cent oxygen mixture, the results were entirely comparable to those already described.

Table II and Figure 2 present the data from one of two other experiments in which the plasma $\mathrm{pCO}_{2}$ was varied without alteration in plasma $\mathrm{pH}$ by simultaneously changing ventilation and the plasma bicarbonate level. Plasma $\mathrm{pH}$ was never lower than 7.53. It can be seen that the effect on bicarbonate reabsorption was similar to that illustrated in Table I and Figure 1. In this experiment, the rise in plasma bicarbonate levels and the increased urine flow during the third and fourth periods were probably due mainly to the large intravenous load of sodium bicarbonate. In the two experiments of this type, prolonged periods of equilibration were required between succesive observation periods in order to adjust plasma bicarbonate and $\mathrm{pCO}_{2}$ to the desired levels.

In Figure 3 are plotted all the data taken from fifty-four observations in the eleven experiments

TABLE I

Effect of changing $\mathrm{CO}_{2}$ tension on bicarbonate reabsorption during metabolic alkalosis

Dog Jackie: Weight $14 \mathrm{Kg}$. Loaded with $180 \mathrm{mEq}$. $\mathrm{NaHCO}_{2}$ at 0 time and sustaining infusion containing 100 $\mathrm{mEq} . / \mathrm{L}$. $\mathrm{NaHCO}_{3}$ and $50 \mathrm{mEq} . / \mathrm{L}$. $\mathrm{NaCl}$ started at $9.5 \mathrm{cc} . / \mathrm{min}$.

\begin{tabular}{|c|c|c|c|c|c|c|c|c|}
\hline \multirow{2}{*}{$\begin{array}{c}\text { Total } \\
\text { elapsed } \\
\text { time, }\end{array}$} & \multicolumn{3}{|c|}{ Plasma } & \multirow{2}{*}{$\begin{array}{l}\text { Glom. } \\
\text { filt. } \\
\text { rate }\end{array}$} & \multirow[b]{2}{*}{$\begin{array}{l}\text { Urine } \\
\text { flow }\end{array}$} & \multicolumn{3}{|c|}{$\left[\mathrm{HCO}_{3}\right]$} \\
\hline & $\mathrm{pH}$ & $\mathrm{pCO}_{2}$ & $\overline{\left[\mathrm{HCO}_{3}\right]}$ & & & Excreted & Reabsorbed & $\begin{array}{c}\text { Reabsorbate } \\
\text { concentration }\end{array}$ \\
\hline \multirow{4}{*}{$\begin{array}{l}\text { min. } \\
103-113 \\
113-123 \\
126 \text { Ventilation } \\
202-212 \\
212-222 \\
223 \text { Ventilation } \\
285-295 \\
295-305 \\
307 \text { Ventilation } \\
346-356\end{array}$} & $\begin{array}{l}7.83 \\
7.84 \\
\text { reduced }\end{array}$ & $\begin{array}{c}m m . H g \\
30 \\
29\end{array}$ & $\begin{array}{c}m E q . / L \\
48.4 \\
47.5\end{array}$ & $\begin{array}{c}c c . / m i n . \\
40 \\
44\end{array}$ & $\begin{array}{c}c c . / m i n . \\
11.3 \\
13.9\end{array}$ & $\begin{array}{c}m q . / \min . \\
1.17 \\
1.35\end{array}$ & $\begin{array}{c}m E q . / \min . \\
.760 \\
.720\end{array}$ & $\begin{array}{c}m E q . / L . \\
26.6 \\
24.3\end{array}$ \\
\hline & $\begin{array}{c}7.46 \\
7.48 \\
\text { increased }\end{array}$ & $\begin{array}{l}83 \\
78\end{array}$ & $\begin{array}{l}55.8 \\
55.3\end{array}$ & $\begin{array}{l}49 \\
41\end{array}$ & $\begin{array}{l}12.9 \\
10.9\end{array}$ & $\begin{array}{l}1.33 \\
1.12\end{array}$ & $\begin{array}{l}1.40 \\
1.16\end{array}$ & $\begin{array}{l}38.8 \\
38.2\end{array}$ \\
\hline & $\begin{array}{l}7.81 \\
7.84\end{array}$ & $\begin{array}{l}36 \\
34\end{array}$ & $\begin{array}{l}53.8 \\
54.1\end{array}$ & $\begin{array}{l}33 \\
30\end{array}$ & $\begin{array}{r}11.3 \\
9.8\end{array}$ & $\begin{array}{l}1.10 \\
1.02\end{array}$ & $\begin{array}{l}.670 \\
.620\end{array}$ & $\begin{array}{l}31.2 \\
30.2\end{array}$ \\
\hline & 7.53 & 73 & 59.4 & 30 & 8.3 & .76 & 1.05 & 47.5 \\
\hline
\end{tabular}




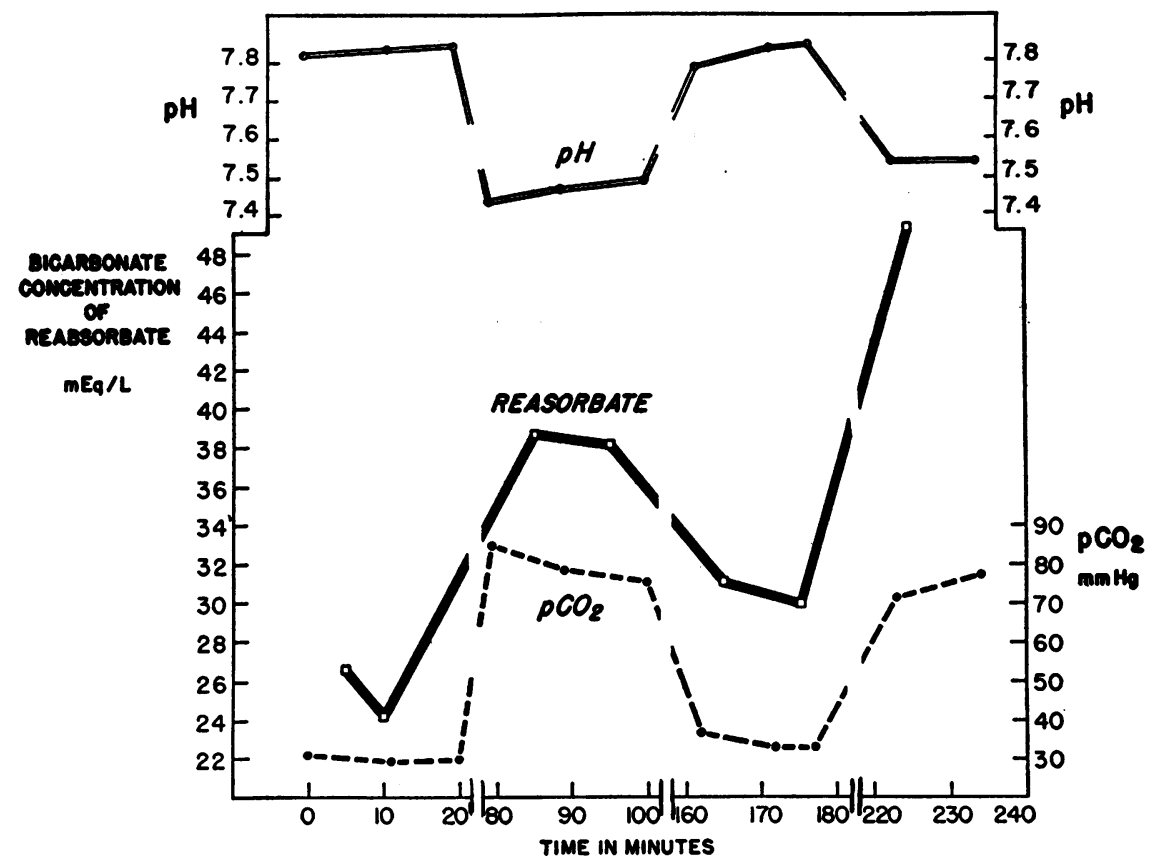

Fig. 1. The Effect of Changing pCO on Bicarbonate Reabsorption in the Presence of Metabolic Alkalosis

In this experiment $\mathrm{pCO}_{2}$ was increased by hypoventilation. The breaks in the ordinate scale, in this figure and in Figure 2, represent the passage of time during equilibration.

reported here. The graph demonstrates the relationship between $\mathrm{pCO}_{2}$ and the bicarbonate concentration of the reabsorbate, when $\mathrm{pCO}_{2}$ is varied between 14 and $91 \mathrm{~mm}$. $\mathrm{Hg}$ in the presence of a metabolic alkalosis ( $\mathrm{pH} 7.45$ to 7.93 ). It can be seen that there is a good, direct linear correlation between these two parameters $(r=.80)$. The correlation between $\mathrm{pCO}_{2}$ and bicarbonate threshold expressed as mEq. $\mathrm{HCO}_{3}$ reabsorbed per 100 cc. GFR $\times 10$ was approximately the same $(r=$ .91); the regression equation for $\mathrm{pCO}_{2}$ on this latter parameter was $\mathrm{y}=.28 \mathrm{x}+12.3$ and the equation for $\mathrm{pCO}_{2}$ on the concentration of the reabsorbate was $\mathrm{y}=.38 \mathrm{x}+13.7$.

\section{DISCUSSION}

It seems clear from these observations that, contrary to previous opinion $(5,6)$, renal bicarbonate

TABLE II

Effect of changing $\mathrm{CO}_{2}$ tension on bicarbonate reabsorption in presence of constant plasma $p H$

Dog Josie: Weight $16 \mathrm{Kg}$. Loaded with $72 \mathrm{mEq} . \mathrm{NaHCO}_{8}$ at 0 time and sustaining infusion containing $45 \mathrm{mEq} . / \mathrm{L}$. $\mathrm{NaHCO}_{3}$ and $105 \mathrm{mEq} . / \mathrm{L}$. $\mathrm{NaCl}$ started at $9.5 \mathrm{cc} . / \mathrm{min}$.

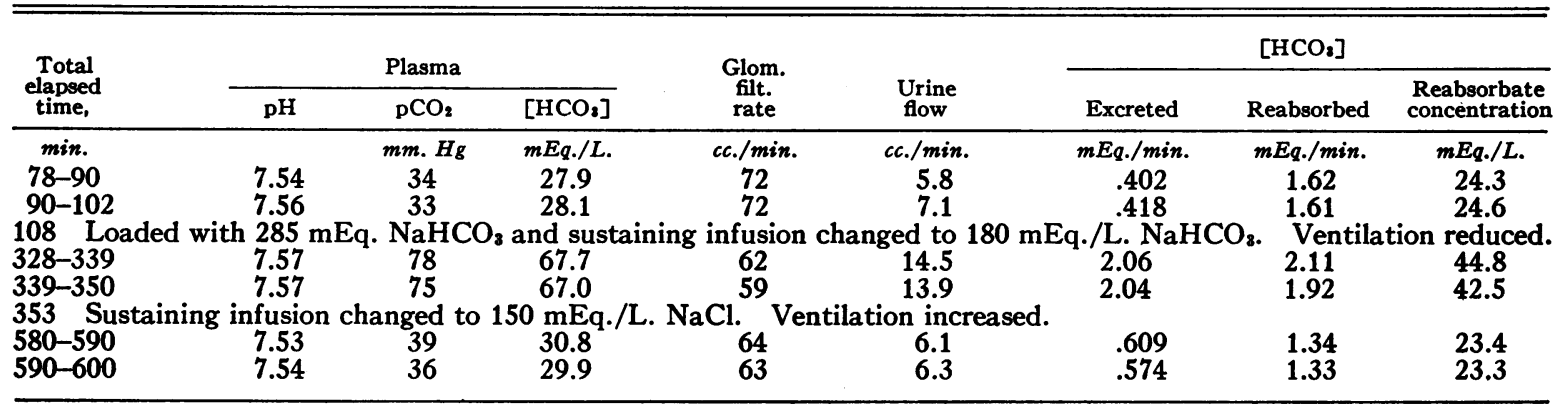




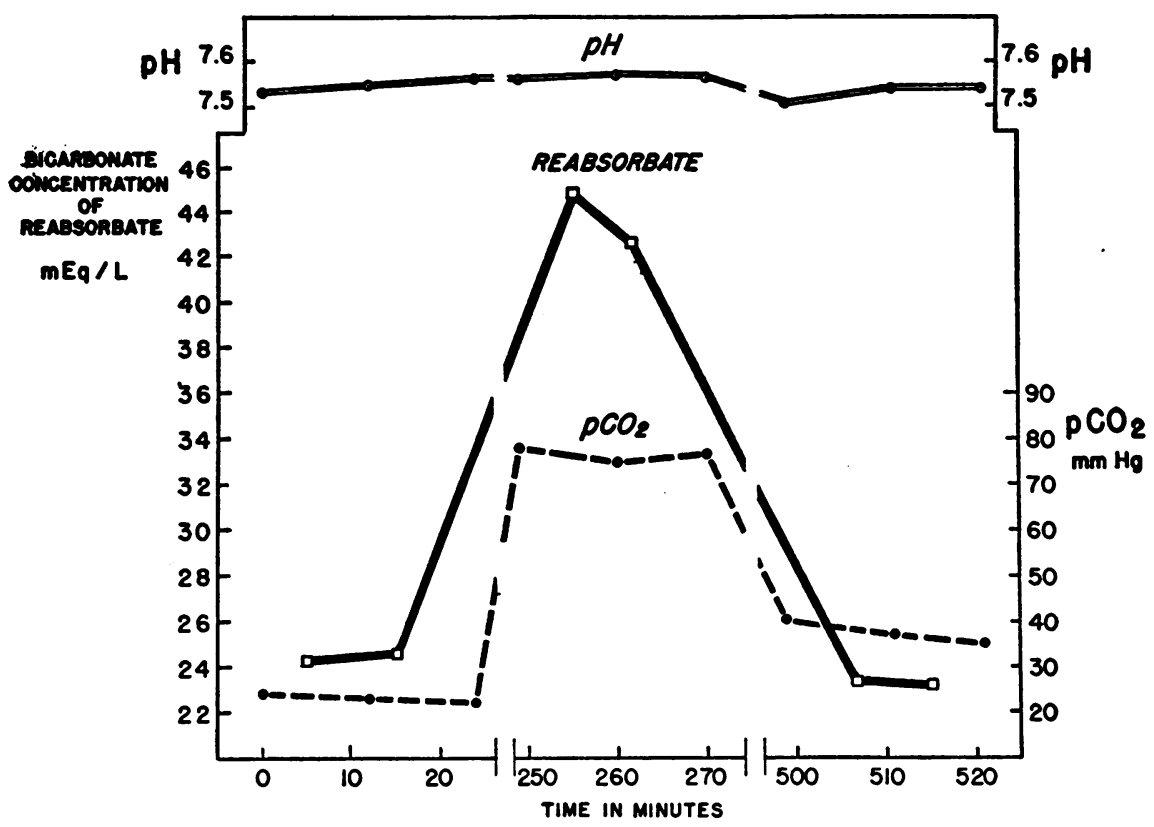

Fig. 2. The Effect of Changing $\mathrm{pCO}_{2}$ on Bicarbonate Reabsorption in the Presence of a Constant, Alraline Plasma pH

The $\mathrm{pH}$ was kept constant by adjustment of plasma bicarbonate level with each change in $\mathrm{pCO}_{2}$.

reabsorption is directly related to the carbon dioxide tension of body fluids and is independent of extracellular fluid $\mathrm{pH}$. The data imply that the increased renal threshold for bicarbonate in respiratory acidosis is the result of the increased carbon dioxide tension and does not depend on either the existence of an extracellular acidosis or on any change in blood pH. The data also imply that alkalinuria in respiratory alkalosis is the result of the lowered plasma carbon dioxide tension and not of the elevated plasma $\mathrm{pH}$.

According to these findings, compensatory hypoventilation in chronic metabolic alkalosis, with an attendant rise in $\mathrm{pCO}_{2}$ should increase renal bicarbonate reabsorption. That bicarbonate reabsorption is, in fact, increased in severe compensated, or partially compensated, metabolic alkalosis is not generally appreciated, although calculation shows that such must usually be the case, even when the urine is alkaline. In Table III are calculated the urine bicarbonate concentrations which would obtain in an hypothetical alkalotic patient with a plasma bicarbonate concentration of 40 mEq. per L. and a "normal" rate of bicarbonate reabsorption, e.g., $2.8 \mathrm{mEq}$. per 100 cc. GFR (2).
The calculation is made for two different values of GFR and three different daily urine volumes. It can be seen that only at very high urine flows and low filtration rates could the urine bicarbonate concentration be less than $200 \mathrm{mEq}$. per L. At the more usual urine flows and glomerular filtra-

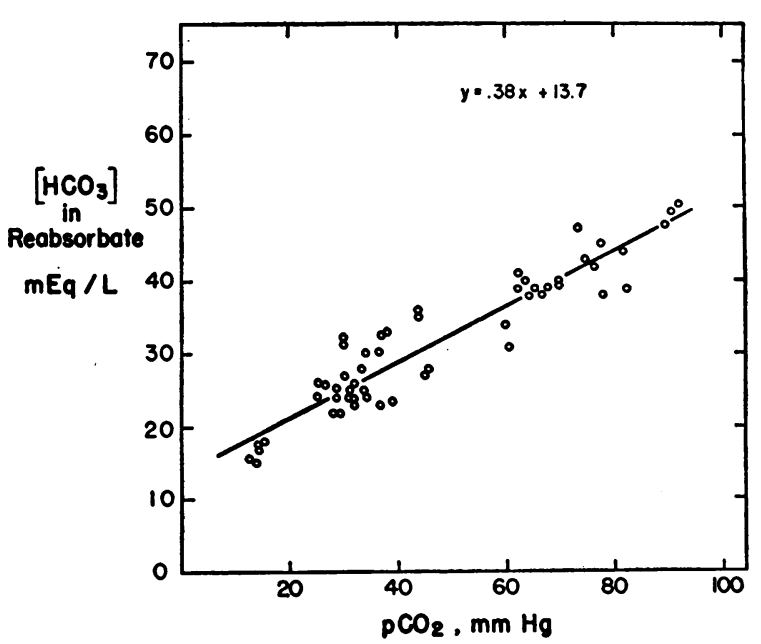

Fig. 3. The Relation of Reabsorbate Bicarbonate Concentration to $\mathrm{pCO}_{2}$ for All Experiments The plasma $\mathrm{pH}$ was never less than 7.45 . 
TABLE III

Urine bicarbonate concentrations which would be required in a patient with a plasma bicarbonate of $40 \mathrm{mEq}$./L. and $a$ "normal" rate of bicarbonate reabsorption (2.8 $m E q . / 100$ cc. GFR)

\begin{tabular}{ccc}
\hline $\begin{array}{c}\text { Glom. filt. rate } \\
\text { cc./min. }\end{array}$ & $\begin{array}{c}\text { Urine volume } \\
\text { Liter/day }\end{array}$ & $\begin{array}{c}\text { Estimated urine HCO, } \\
\text { concentration } \\
m E q . / L .\end{array}$ \\
\hline 100 & 1 & 1730 \\
& 2 & 865 \\
50 & 5 & 346 \\
& 1 & 865 \\
& 2 & 432 \\
& 5 & 173 \\
\hline
\end{tabular}

tion rates, "normal" rates of bicarbonate reabsorption would result in urine concentrations much higher than the highest values observed during extreme bicarbonate loading in man and dog (1-3). Furthermore, the calculated daily bicarbonate excretion would be large enough to remove rapidly excess alkali from the body in almost all conceivable clinical situations.

It is, therefore, probable that in most patients with severe chronic alkalosis renal reabsorption of bicarbonate is increased even when the urine is alkaline. The difference between these patients with alkaline urines, and those with so-called "paradoxical aciduria," is probably only a matter of degree since it would appear that neither group is excreting bicarbonate "normally." The rise in bicarbonate reabsorption resulting from hypercapnia is clearly useful to the organism defending against respiratory acidosis, but it appears to be inappropriate in metabolic alkalosis where it restricts the renal elimination of alkali and tends to perpetuate the elevation of the plasma bicarbonate concentration. It is probably fortunate for the organism that the respiratory response to acute metabolic alkalosis is often slow (9) and incomplete $(2,3)$ because the kidney is thereby permitted to excrete the excess alkali at a maximal rate and restore plasma bicarbonate, as well as plasma $\mathrm{pH}$, to normal values.

Although the evidence presented here indicates that any compensatory retention of carbon dioxide will tend to elevate the renal bicarbonate threshold in alkalosis, other factors may be operating as well. Sodium depletion $(4,6,10)$ and potassium depletion (11) have been implicated as causes of "paradoxical aciduria," and recently it has been shown that acute experimental reductions in glomerular filtration rate will also raise the renal bicarbonate threshold (12). One or more of these latter factors may act together with an elevated $\mathrm{pCO}_{2}$ to decrease bicarbonate excretion in any particular case of chronic alkalosis. For example, in the case of gastric alkalosis with "paradoxical aciduria" studied by Kennedy, Winkley, and Dunning (13) the plasma $\mathrm{PCO}_{2}$ was about $60 \mathrm{~mm}$. $\mathrm{Hg}$, but there was also severe potassium depletion as well as a moderate reduction in glomerular filtration rate. The present experiments were also occasionally complicated by small variations in GFR (Table I), and all animals developed some degree of hypokaliemia as the result of prolonged loading with sodium bicarbonate solutions (14). The scatter of points in Figure 3, as well as the failure of $\mathrm{pCO}_{2}$ to correlate strictly with bicarbonate reabsorption in some individual dogs (Figure 1), may be attributable in part to one or both of these factors.

Despite the probability that reabsorbate concentration is also affected by changes in urine flow (15), the correlation between $\mathrm{pCO}_{2}$ and reabsorbate concentration was chosen for illustration because it best describes how changes in $\mathrm{pCO}_{2}$ would affect renal regulation of plasma concentration under normal circumstances. It should be noted, however, that bicarbonate reabsorption calculated as mEq. per $100 \mathrm{cc}$. GFR correlates with $\mathrm{pCO}_{2}$ in essentially the same way. This indicates that despite the variations in urine flow, the use of reabsorbate concentration is valid for the purposes of discussion in this study.

Examination of Figure 3 suggests that the relation betwen $\mathrm{pCO}_{2}$ and reabsorbate concentration may be the manifestation of a renal mechanism tending to stabilize extracellular fluid $\mathrm{pH}$. If one assumes a constant, normal $\mathrm{pH}$ of 7.35 for the dog, it is possible to calculate from the HendersonHasselbalch equation a theoretical relationship between $\mathrm{pCO}_{2}$ and reabsorbate concentration. This line $(\mathrm{y}=.53 \mathrm{x})$ has a slope very similar to that of the observed regression line $(\mathrm{m}=.38)$, although the latter defines a small variation in reabsorbate $\mathrm{pH}\left(\mathrm{pH} 7.48\right.$ at $\mathrm{pCO}_{2}=40 \mathrm{~mm}$. $\mathrm{Hg} ; \mathrm{pH} 7.36$ at $\mathrm{pCO}_{2}=80 \mathrm{~mm}$. $\mathrm{Hg}$ ). It is impossible from the data at hand to determine how much of this variation may be due to experimental error or to complicating factors such as potassium depletion. 
However, even if the observed line is an accurate description of the renal response, the relatively narrow limits of $\mathrm{pH}$ variation indicate that the mechanism would defend extracellular $\mathrm{pH}$ with considerable efficiency over a wide range of $\mathrm{pCO}_{2}$. The existence of such a mechanism is further suggested by the clinical observation (16) that extracellular $\mathrm{pH}$ is often within normal limits in patients with primary $\mathrm{CO}_{2}$ excess.

These experiments provide no clue to the means by which the $\mathrm{pCO}_{2}$ exerts its effect on bicarbonate reabsorption. One possibility is that hypercapnia increases acidity within renal tubular cells, producing a condition comparable to that resulting from potassium deficiency $(11,14)$. Another possibility is that the high $\mathrm{pCO}_{2}$ increases carbonic anhydrase activity (17) and thereby accelerates bicarbonate transport. Experiments to be reported from this laboratory (18) indicate that renal carbonic anhydrase activity is probably increased when $\mathrm{pCO}_{2}$ is high and that under these circumstances the increased enzyme activity may be responsible for the augmented transport of bicarbonate.

\section{SUMMARY AND CONCLUSIONS}

There is a direct, approximately linear relationship between plasma carbon dioxide tension and renal bicarbonate reabsorption in the anesthetized dog which can be demonstrated in the presence of extracellular alkalosis and does not require any change in pulmonary ventilation or in extracellular $\mathrm{pH}$. It is suggested that renal adjustment of bicarbonate reabsorption is related to carbon dioxide tension in a manner which tends to preserve the neutrality of the reabsorbate and the extracellular fluid. The data indicate that changes in $\mathrm{pCO}_{2}$ are primarily responsible for the increased bicarbonate threshold in respiratory acidosis and the reduced threshold in respiratory alkalosis. Respiratory compensation of metabolic alkalosis increases the bicarbonate threshold and thus tends to perpetuate the elevation of extracellular bicarbonate concentration.

The mechanism of action of $\mathrm{pCO}_{2}$ on bicarbonate transport is not revealed by these experiments, but it is suggested that changes in acidity or carbonic anhydrase activity within renal tubular cells may be responsible.

\section{ACKNOWLEDGMENTS}

The authors are indebted to Miss Jacquelyn Allen, Miss Helen Connors, Mr. Joseph Greaney, Mrs. Elizabeth Hughes, Miss Sonja Jeffress, Mrs. Mary Kimball, and Miss Arlene Roy for their invaluable technical assistance.

Addendum. Independent observations by $P$. Brazeau and A. Gilman (Federation Proc., 1953, 12, 19) and by P. J. Dorman and W. J. Sullivan (Personal communication) are in substantial agreement with the findings reported here.

\section{REFERENCES}

1. Pitts, R. F., and Lotspeich, W. D., Bicarbonate and the renal regulation of acid-base balance. Am. J. Physiol., 1946, 147, 138.

2. Pitts, R. F., Ayer, J. L., and Schiess, W. A., The renal regulation of acid-base balance in man. III. The reabsorption and excretion of bicarbonate. $\mathrm{J}$. Clin. Invest., 1949, 28, 35.

3. Davies, H. W., Haldane, J. B. S., and Kennaway, E. L., Experiments on the regulation of the blood's alkalinity. I. J. Physiol., 1920, 54, 32.

4. McCance, R. A., and Widdowson, E. M., The response of the kidney to an alkalosis during salt deficiency. Proc. Roy. Soc., London, S.B., 1936, $120,228$.

5. Stanbury, S. W., and Thomson, A. E., The renal response to respiratory alkalosis. Clin. Sc., 1952, 11, 357.

6. Peters, J. P., and Van Slyke, D. D., Quantitative Clinical Chemistry, Vol. I, Interpretations, The Williams \& Wilkins Co., Baltimore, 1932, p. 953.

7. Roe, J. H., Epstein, J. H., and Goldstein, N. P., A photometric method for the determination of inulin in plasma and urine. J. Biol. Chem., 1949, 178, 839.

8. Van Slyke, D. D., and Neill, J. M., The determination of gases in blood and other solutions by vacuum extraction and manometric measurement. J. Biol. Chem., 1924, 61, 523.

9. West, C. D., and Rapoport, S., Absence of respiratory change or manifest tetany with elevation of plasma $\mathrm{pH}$ produced by bicarbonate administration in dogs. J. Lab. \& Clin. Med., 1950, 36, 428.

10. Gamble, J. L., and Ross, S. G., The factors in the dehydration following pyloric obstruction. J. Clin. Invest., 1924, 1, 403.

11. Berliner, R. W., Kennedy, T. J., Jr., and Orloff, J., Relationship between acidification of the urine and potassium metabolism. Effect of carbonic anhydrase on potassium excretion. Am. J. Med., 1951, 11, 274.

12. Thompson, D. D., and Barrett, M. J., Effects of variations in glomerular filtration rate on bicarbonate reabsorption. Federation Proc., 1953, 12, 144. 
13. Kennedy, T. J., Jr., Winkley, J. H., and Dunning, M. F., Gastric alkalosis with hypokalemia. Am. J. Med., 1949, 6, 790.

14. Roberts, K. E., Magida, M. G., and Pitts, R. F., Relationship between potassium and bicarbonate in blood and urine. Am. J. Physiol., 1953, 172, 47.

15. Smith, H. W., The Kidney, Oxford University Press, New York, 1951.
16. Schwartz, W. B., and Relman, A. S., Unpublished observations.

17. Roughton, F. J. W., and Booth, V. H., The effect of substrate concentration $\mathrm{pH}$ and other factors upon the activity of carbonic anhydrase. Biochem. J., 1946, 40, 319.

18. Schwartz, W. B., Tobias, G. J., Greaney, J. F., and Relman, A. S., To be published. 